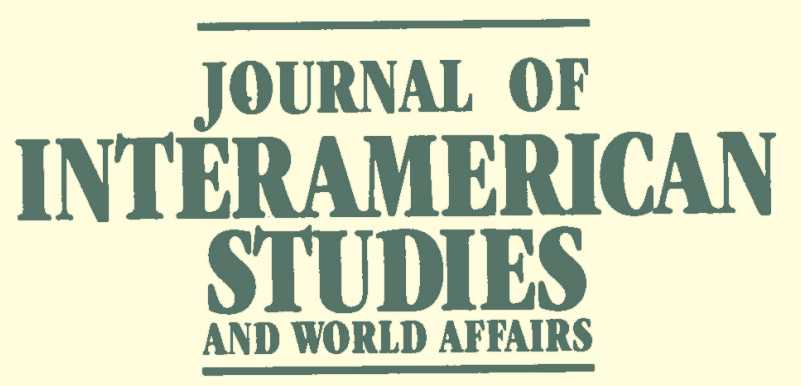

Volume 32, Number 4 Winter 1990

The Enterprise for the Americas Initiative: A New Approach to Economic Growth Roger B. Porter

Elections and Democratization in Nicaragua:

The 1990 Elections in Perspective Philip J. Williams

Soviet Policy toward Latin America: Time for Renewal Fernando Bustamante

The Role of the Paraguayan Catholic Church in the Downfall of the Stroessner Regime Miguel Carter

\title{
THE DRUG TRADE REVISITED
}

United States International Drug Policy:

Recent Developments and Issues

Raphael F. Perl

The Economic Impact of Andean Cocaine Traffic

on Florida

Robert Grosse

BOOK REVIEWS 


\section{EDITORIAL STAFF}

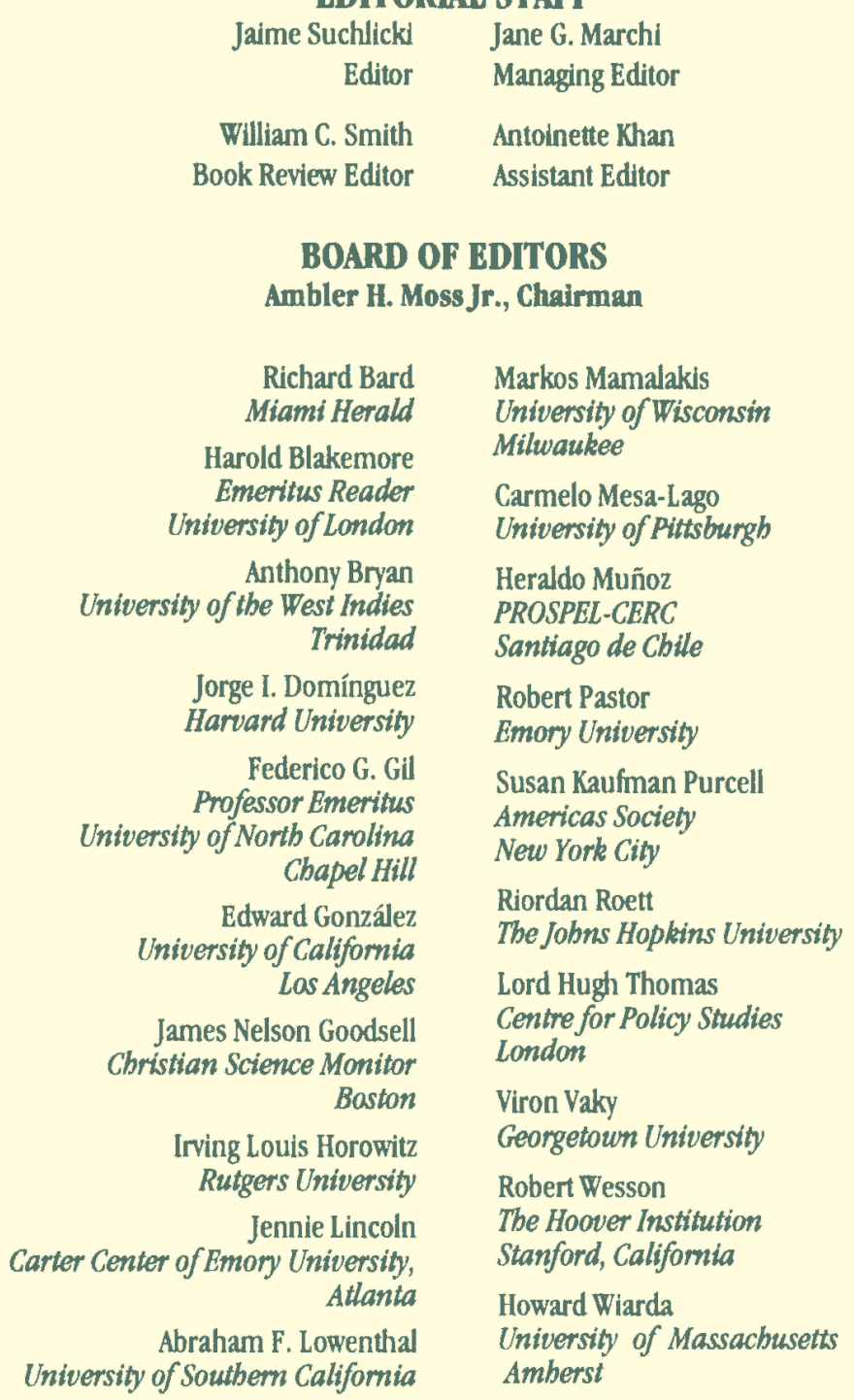

(C) Copyright 1990 University of Miami

Published for the

Institute of Interamerican Studies

by the

North-South Center, University of Miami

Ambler H. Moss, Jr.

Director

Julian 1. Weinkle

Deputy Director 


\section{JOURNAL OF INTERAMERICAN STUDIES AND WORLD AFFAIRS}

The Enterprise for the Americas Initiative: A New Approach

to Economic Growth

Roger B. Porter

Elections and Democratization in Nicaragua:

13 The 1990 Elections in Perspective

Philip J. Williams

Soviet Policy toward Latin America: Time for Renewal

35

Fernando Bustamante

The Role of the Paraguayan Catholic Church

67

in the Downfall of the Stroessner Regime Miguel Carter

\section{THE DRUG TRADE REVISITED}

United States International Drug Policy:

Recent Developments and Issues

Raphael F Perl

The Economic Impact of Andean Cocaine Traffic on Florida

Robert Grosse 

published four times annually by the University of Miami North-South Center for the Institute of Interamerican Studies, P.O. Box 248123, Coral Gables, FL 33124 . Copyright 1990 by the University of Miami, Institute of Interamerican Studies. All rights reserved. No portion of the contents may be reproduced in any form without written permission of the publisher.

Authorization to photocopy items for internal or personal use, or the internal or personal use of specific clients, is granted by the University of Miami, Institute of Interamerican Studies, for libraries and other users registered with the Copyright Clearance Center (CCC) Transactional Reporting Service, providing that the base fee of $25 \notin$ per copy, plus $10 \AA$ per copy page, is paid directly to CCC, 21 Congress St., Salem, MA 01970.

The JOURNAL is abstracted or indexed in Historical Abstracts, International Political Science Abstracts, Public Affairs Information Service, Current Contents, Social Sciences Citation Index, Social Sciences Index, ABC POL SCI, and United States Political Science Documents; it also is available on $16 \mathrm{~mm}$ microfilm, $35 \mathrm{~mm}$ microfilm, and $105 \mathrm{~mm}$ microfiche from University Microfilms, Inc., Ann Arbor, Michigan.

SUBSCRIPTIONS: As of January 1991, per year institutional rate will be $\$ 64.00$; individuals, $\$ 32.00$; continental US students only (with proof of current registration), $\$ 16.00$. Mailed second class postage paid from Miami, FL, USA. Rates for international subscribers are $\$ 84.00$ for institutions, $\$ 42.00$ for individuals.

BACK ISSUES: Information about availability and price of back issues may be obtained from the publisher's order department at address below.

INQUIRIES: Address all correspondence and permission requests to University of Miami, JOURNAL OF INTERAMERICAN STUDIES AND WORLD AFFAIRS, P.O. BOX 248123, Coral Gables, FL 33124, USA. 